Article

\title{
Natural Formulation Based on Diatomaceous Earth and Botanicals against Stored Product Insects
}

\author{
Ivan Paponja ${ }^{1}$, Vlatka Rozman ${ }^{2}$ and Anita Liška ${ }^{2, *(1)}$ \\ 1 Faculty of Agrobiotechnical Sciences Osijek, Josip Juraj Strossmayer University of Osijek, \\ 31000 Osijek, Croatia; paponja.ivan1@gmail.com \\ 2 Department for Phytomedicine, Faculty of Agrobiotechnical Sciences Osijek, Josip Juraj Strossmayer \\ University of Osijek, 31000 Osijek, Croatia; vrozman@fazos.hr \\ * Correspondence: aliska@fazos.hr
}

Received: 29 July 2020; Accepted: 7 September 2020; Published: 8 September 2020

Simple Summary: Stored product insects play a major role in postharvest loss. In order to minimize negative effect of conventional insecticides, diatomaceous earth (DE) is one of the alternative solutions for insect control. Despite favorable effect for the environment and human health, DE has some negative side effects on the treated commodity. In order to overcome the limitations of DEs, the aim of this study was to develop natural formulation which would improve the activity of DE. Formulation (labeled as N Form) based on DE enhanced with botanicals and silica gel was tested against three major stored product insect species in wheat and barley under controlled conditions. $\mathrm{N}$ Form showed higher efficacy than DE, especially in barley, inducing higher mortality of all three insect species. This study provides new information about the improvement of DE effectiveness thus representing a contribution to further development of natural insecticides as a part of integrated pest management.

\begin{abstract}
Diatomaceous earth (DE) has long been known as a potential protectant for stored cereals against various stored product insects. Despite favorable effect for the environment and human health, DE has some negative side effects on the treated commodity. In order to minimize negative response and to improve its efficacy, this paper represents a study of developed natural formulation based on DE SilicoSec ${ }^{\circledR}$ enhanced with botanicals (essential oil lavender, corn oil, and bay leaves dust) and silica gel. The activity of formulation (labeled as N Form) was tested against Sitophilus oryzae (L.), Rhyzopertha dominica (F.), and Tribolium castaneum (Herbst) in seed wheat and barley under controlled conditions. As a reference comparative value, DE SilicoSec ${ }^{\circledR}$ was used. N Form showed higher efficacy than DE, especially in barley at the lowest concentration, inducing higher mortality of all three insect species. The highest average progeny inhibition was recorded in $R$. dominica population both in seed wheat and barley with $94.9 \%$ and $96.3 \%$ of inhibition, respectively, followed with S. oryzae and T. castaneum inhibition of $90.6 \%$ and $86.1 \%$, respectively, in wheat and $94.9 \%$ and $89.7 \%$, respectively, in barley. Results indicate that the developed natural formulation N Form enhanced the activity of DE SilicoSec ${ }^{\circledR}$ using lower amount of DE dust and that it could be successfully implemented for storage of cereals as alternatives to chemical pesticides for stored product insect control.
\end{abstract}

Keywords: diatomaceous earth; essential oil; lavender; botanicals; stored product insects

\section{Introduction}

Stored product insects play a major role in postharvest loss, both quantitative and qualitative. Thus, it is a great challenge to minimize grain losses during storage and important to use efficient insecticides that are safe for humans and the environment. 
The use of diatomaceous earth (DE) provides most of these requirements. Its main advantages are low mammalian toxicity and long persistence [1] with efficient insecticidal activity without leaving hazardous residues [2,3]. Yet, there are some limitations, which impede wider commercial use of $\mathrm{DE}$, such as reduction of bulk density and flowability of grain [4,5], creation of dusty environment, and decrease in efficacy at higher grain moisture contents [6] and variable efficacy based on type of commodity (rice, sorghum, rye, corn, or wheat) [7]. Due to a desiccating mode of action, DEs are slow-acting insecticides. They are less effective against insects developing inside the kernel. Consequently, efficacy can differ among some insect species [2,5,8] and different development stages [9].

In order to overcome the limitations of DEs, diverse studies were conducted to discover new ways of DE use [10]. One attempt was mixing DE with botanicals, plant extracts [11], or essential oils (EO) [12], which revealed enhanced and synergistic effectiveness [13,14]. Silica gels, which are produced by drying aqueous solutions of sodium silicate, are very light hydrophobic powders [15]. Dehydration is also the main cause of insect death [16], but unlike DE, silica gel has the advantage of a much larger surface area than diatomaceous earth [15] and has very fast initial effectiveness [3].

In light of these findings, the aim was to incorporate benefits of botanicals, silica gel, and DE into a powder formulation, which would provide higher efficacy than DE used alone. In this study, the activity of developed formulation labelled as N Form was tested against three stored product insect species: the rice weevil Sitophilus oryzae (L.) (Coleoptera: Curculionidae), the lesser grain borer Rhyzopertha dominica (F.) (Coleoptera: Bostrychidae), and the red flour beetle Tribolium castaneum (Herbst) (Coleoptera: Tenebrionidae) under controlled conditions.

\section{Materials and Methods}

\subsection{Natural Formulation}

Powder formulation labeled as N Form was based on diatomaceous earth (DE) SilicoSec ${ }^{\circledR}$ $(48 \% w t / w t)$, silica gel SIPERNAT ${ }^{\circledR} 50 \mathrm{~S}(24 \% w t / w t)$, dried and milled bay leaves $(20 \% w t / w t)$, corn oil $(3 \% w t / w t)$, essential oil (EO) of lavender Lavandula $x$ intermedia $(2 \% w t / w t)$, and unactivated yeast as a food grade bait. All ingredients were mixed together on an electromagnetic sieve shaker (CISA RP08) using sieve with mesh size of $500 \mu \mathrm{m}$. Prepared N Form was kept in hermetically sealed bottles until application.

\subsection{Test Insects}

The insecticidal effect of the formulation $\mathrm{N}$ form was evaluated on three stored product insect species, two internal feeders, S. oryzae and R. dominica and one external feeder, T. castaneum. Test insects have been reared under the controlled conditions at $28 \pm 1{ }^{\circ} \mathrm{C}$ and $65 \pm 5 \%$ relative humidity (r.h.) on whole soft white wheat (for S. oryzae and R. dominica) and on mixture of wheat flour and $5 \%$ brewer's yeast by weight (for T. castaneum). All adults used in the test treatments were 7-21 days old.

\subsection{Commodity}

For the experiment, Croatian varieties of wheat and barley were used. High-yielding winter barley variety Bingo (protein content $11.02 \%$ and oil content $11 \%$ ) had initial moisture content (m.c.) of $15.2 \%$ and $75.8 \mathrm{~kg} \mathrm{hL}^{-1}$ test weight and high-yielding winter wheat variety Anđelka (protein content $13.0 \%$ and oil content $12.5 \%$ ) had $12.7 \%$ of initial m.c. and $74.7 \mathrm{~kg} \mathrm{hL}^{-1}$ test weight. Moisture content and test weight of wheat and barley were measured by the GAC 2100-Agri Grain analysis computer (Dickey-john). Prior to use in bioassay, the seed was cleaned and sterilized at $50{ }^{\circ} \mathrm{C}$ and acclimated for $7 \mathrm{~d}$ at $28 \pm 1{ }^{\circ} \mathrm{C}$ and $65 \pm 5 \%$ r.h. to maintain the level of moisture content at specified limit.

\subsection{Bioassay in Controlled Conditions}

The formulation N Form was applied as dust to seeds in 4 different concentrations (300, 400, 500, and $600 \mathrm{ppm}$ ). Glass jars of $200 \mathrm{~mL}$ volume were filled with $100 \mathrm{~g}$ of clean wheat or barley, respectively, 
and determined concentrations of the tested formulation were added. Jars were tightly closed with lids and thoroughly shaken for $30 \mathrm{~s}$ for equal distribution of added dust over the seeds. After the dust settled, 20 unsexed, 7-21 days old adults of S. oryzae, $R$. dominica, or T. castaneum were added into each jar period. Jars were closed with perforated lids and left in control conditions $\left(28 \pm 1^{\circ} \mathrm{C}\right.$ and $60 \pm 5 \%$ r.h.). Adults' mortality and progeny reduction were evaluated. Adults' mortality was evaluated after 7 and $14 \mathrm{~d}$ of exposure on the same set of jars. After the assessment of adult mortality, all adults were removed and remaining seeds with laid eggs were left under controlled conditions for 7-9 weeks (for S. oryzae and for R. dominica and T. castaneum, respectively) to evaluate the emerged progeny. All treatments were replicated three times for each concentration, separately for each insect species and type of seed. The same procedure was followed for the untreated wheat and barley that served as control. As a reference comparative value, DE SilicoSec ${ }^{\circledR}$ was used and tested at the same concentrations and within the identical treatment as $\mathrm{N}$ Form.

\subsection{Data Analysis}

Generally, control mortality was, in most cases, $0 \%$, except in barley mortality of S. oryzae, which ranged from $0 \%$ to $6.5 \%$. The mortality data of exposed adult insect species (from the bioassay in controlled conditions) and progeny population (with the control included) were processed by SAS v9.3 (SAS/STAT Software 9.3 2013-2014). One-way analysis of variance of the tested variables was subjected in SAS Analyst module and the procedure of ANOVA was used. Tukey's HSD $(p<0.05)$ test was used to detect differences among means of examined traits.

\section{Results}

\section{Mortality in Controlled Conditions}

In wheat, the tested formulation N Form showed high efficiency against all three insect species especially after 14 days of exposure (Table 1 ). The most sensitive species was $S$. oryzae with the highest mortality reached at concentration of $400 \mathrm{ppm}$, followed by $R$. dominica with $100 \%$ mortality at concentration of $600 \mathrm{ppm}$, while mortality of T. castaneum ranged from $76.6 \%$ to $96.6 \%$ after 14 days of exposure. Comparing the activity of $\mathrm{N}$ form and the activity of DE SilicoSec ${ }^{\circledR}$ per each concentration, although there was no statistical difference, a higher activity of $\mathrm{N}$ Form was observed against $T$. castaneum and $R$. dominica after 7 and 14 days of exposure.

In barley, the tested formulation N Form induced $100 \%$ mortality of all three insect species at 600 ppm after 7 days of exposure (Table 2). There was no statistical difference among concentrations. Comparing the activity of $\mathrm{N}$ form and the activity of $\mathrm{DE}$ SilicoSec ${ }^{\circledR}$, a statistical higher mortality against all three insect species was observed with N Form at lower applied concentrations (300 and $400 \mathrm{ppm}$ ).

After the assessment of progeny population developed from treated adults a significant inhibition was observed at the lowest concentration of N Form in all three insect species, both in wheat and barley (Table 3). There were no statistical differences in number of adults among concentrations for each species. In barley, formulation, $\mathrm{N}$ Form reached higher average progeny inhibition rate of all three insect species than in wheat $(94.9 \%$ and $90.6 \%$, respectively, for S. oryzae, $96.4 \%$ and $95.0 \%$, respectively, for R. dominica, and $89.7 \%$ and $86.1 \%$, respectively, for T. castaneum). Further, N Form had higher average progeny inhibition rate than DE SilicoSec ${ }^{\circledR}$, particularly in barley for all three insect species. 
Table 1. Mean (\% \pm SD) mortality of Tribolium castaneum, Sitophilus oryzae, and Rhyzopertha dominica adults after 7 and $14 \mathrm{~d}$ of exposure to treated wheat seeds with formulation N Form and DE SilicoSec ${ }^{\circledR}$.

\begin{tabular}{|c|c|c|c|}
\hline \multirow{2}{*}{ Treatment } & \multirow{2}{*}{ Concentration (ppm) } & \multicolumn{2}{|c|}{ Mean $\left(\% \pm\right.$ SD $\left.^{a}\right)$ Mortality } \\
\hline & & $7 \mathrm{~d}$ of Exposure & $14 \mathrm{~d}$ of Exposure \\
\hline \multicolumn{4}{|c|}{ Tribolium castaneum } \\
\hline \multirow{4}{*}{ N Form } & 300 & $23.3 \pm 15.27$ & $76.6 \pm 12.58 \mathrm{ab}$ \\
\hline & 400 & $45.0 \pm 13.22$ & $86.6 \pm 14.53 \mathrm{a}$ \\
\hline & 500 & $40.0 \pm 35.00$ & $78.3 \pm 29.29 \mathrm{ab}$ \\
\hline & 600 & $30.0 \pm 13.22$ & $96.6 \pm 5.77 \mathrm{a}$ \\
\hline \multirow{5}{*}{ SilicoSec ${ }^{\circledR}$} & 300 & $3.3 \pm 2.88$ & $36.6 \pm 5.77 b$ \\
\hline & 400 & $16.6 \pm 2.89$ & $55.0 \pm 5.0 \mathrm{ab}$ \\
\hline & 500 & $21.6 \pm 12.58$ & $70.0 \pm 13.22 \mathrm{ab}$ \\
\hline & 600 & $48.3 \pm 24.66$ & $88.3 \pm 20.20 \mathrm{a}$ \\
\hline & $\mathrm{F} / \mathrm{P}$ & $2.18 / 0.0934$ & $4.83 / 0.0044$ \\
\hline \multicolumn{4}{|c|}{ Sitophilus oryzae } \\
\hline \multirow{4}{*}{ N Form } & 300 & $71.6 \pm 10.40 \mathrm{~b}$ & $86.6 \pm 18.92$ \\
\hline & 400 & $95.0 \pm 5.00 \mathrm{a}$ & $100.0 \pm 0.00$ \\
\hline & 500 & $98.3 \pm 2.88 \mathrm{a}$ & $100.0 \pm 0.00$ \\
\hline & 600 & $98.3 \pm 2.88 \mathrm{a}$ & $98.3 \pm 2.88$ \\
\hline \multirow{5}{*}{ SilicoSec ${ }^{\circledR}$} & 300 & $86.6 \pm 7.63 \mathrm{ab}$ & $98.3 \pm 2.88$ \\
\hline & 400 & $81.6 \pm 7.63 \mathrm{ab}$ & $100.0 \pm 0.00$ \\
\hline & 500 & $86.6 \pm 7.63 \mathrm{ab}$ & $100.0 \pm 0.00$ \\
\hline & 600 & $96.6 \pm 5.77 \mathrm{a}$ & $100.0 \pm 0.00$ \\
\hline & $\mathrm{F} / \mathrm{P}$ & $6.06 / 0.0014$ & $1.36 / 0.2875$ \\
\hline \multicolumn{4}{|c|}{ Rhyzopertha dominica } \\
\hline \multirow{4}{*}{ N Form } & 300 & $63.3 \pm 15.27 \mathrm{ab}$ & $76.6 \pm 20.20 \mathrm{ab}$ \\
\hline & 400 & $66.6 \pm 15.27 \mathrm{ab}$ & $85.0 \pm 18.02 \mathrm{ab}$ \\
\hline & 500 & $86.6 \pm 15.27 \mathrm{a}$ & $98.3 \pm 2.88 \mathrm{a}$ \\
\hline & 600 & $83.3 \pm 5.77 \mathrm{a}$ & $100.0 \pm 0.00 \mathrm{a}$ \\
\hline \multirow{5}{*}{ SilicoSec $^{\circledR}$} & 300 & $36.6 \pm 7.63 \mathrm{~b}$ & $63.3 \pm 7.63 \mathrm{~b}$ \\
\hline & 400 & $61.6 \pm 10.40 \mathrm{ab}$ & $85.0 \pm 13.22 \mathrm{ab}$ \\
\hline & 500 & $80.0 \pm 10.00 \mathrm{a}$ & $90.0 \pm 10.00 \mathrm{ab}$ \\
\hline & 600 & $71.6 \pm 17.55 \mathrm{ab}$ & $90.0 \pm 5.0 \mathrm{ab}$ \\
\hline & $\mathrm{F} / \mathrm{P}$ & $4.67 / 0.0051$ & $3.06 / 0.0301$ \\
\hline
\end{tabular}

a Means in the same column within each insect species followed by the same letters are not significantly different (for all treatments $d f=7$, 23; Tukey's HSD, $p=0.05$ ). 
Table 2. Mean (\% $\%$ SD) mortality of Tribolium castaneum, Sitophilus oryzae, and Rhyzopertha dominica adults after 7 and $14 \mathrm{~d}$ of exposure to treated barley seeds with formulation N Form and DE SilicoSec ${ }^{\circledR}$.

\begin{tabular}{|c|c|c|c|}
\hline \multirow{2}{*}{ Treatment } & \multirow{2}{*}{ Concentration (ppm) } & \multicolumn{2}{|c|}{ Mean $\left(\% \pm \mathrm{SD}^{\mathrm{a}}\right)$ Mortality } \\
\hline & & $7 \mathrm{~d}$ of Exposure & $14 \mathrm{~d}$ of Exposure \\
\hline \multicolumn{4}{|c|}{ Tribolium castaneum } \\
\hline \multirow{4}{*}{ N Form } & 300 & $73.3 \pm 24.66 \mathrm{ab}$ & $81.6 \pm 14.43 \mathrm{a}$ \\
\hline & 400 & $96.6 \pm 5.77 \mathrm{a}$ & $98.3 \pm 2.88 \mathrm{a}$ \\
\hline & 500 & $96.6 \pm 2.88 \mathrm{a}$ & $100.0 \pm 0.00 \mathrm{a}$ \\
\hline & 600 & $100.0 \pm 0.00 \mathrm{a}$ & $100.0 \pm 0.00 \mathrm{a}$ \\
\hline \multirow{5}{*}{ SilicoSec ${ }^{\circledR}$} & 300 & $10.0 \pm 8.66 c$ & $50.0 \pm 18.02 b$ \\
\hline & 400 & $46.6 \pm 23.9 \mathrm{bc}$ & $90.0 \pm 10.00 \mathrm{a}$ \\
\hline & 500 & $80.0 \pm 8.66 \mathrm{ab}$ & $96.6 \pm 5.77 \mathrm{a}$ \\
\hline & 600 & $83.3 \pm 7.63 \mathrm{ab}$ & $100.0 \pm 0.00 \mathrm{a}$ \\
\hline & $\mathrm{F} / \mathrm{P}$ & $16.42 /<0.0001$ & $10.57 /<0.0001$ \\
\hline \multicolumn{4}{|c|}{ Sitophilus oryzae } \\
\hline \multirow{4}{*}{ N Form } & 300 & $95.0 \pm 8.66 \mathrm{a}$ & $100.0 \pm 0.00$ \\
\hline & 400 & $95.0 \pm 5.00 \mathrm{a}$ & $100.0 \pm 0.00$ \\
\hline & 500 & $98.3 \pm 2.88 \mathrm{a}$ & $100.0 \pm 0.00$ \\
\hline & 600 & $100.0 \pm 0.00 \mathrm{a}$ & $100.0 \pm 0.00$ \\
\hline \multirow{5}{*}{ SilicoSec ${ }^{\circledR}$} & 300 & $63.3 \pm 10.40 b$ & $98.3 \pm 2.88$ \\
\hline & 400 & $75.0 \pm 10.00 \mathrm{~b}$ & $91.6 \pm 14.43$ \\
\hline & 500 & $96.6 \pm 5.77 \mathrm{a}$ & $100.0 \pm 0.00$ \\
\hline & 600 & $100.0 \pm 0.00 \mathrm{a}$ & $100.0 \pm 0.00$ \\
\hline & $\mathrm{F} / \mathrm{P}$ & $12.72 /<0.0001$ & $0.95 / 0.5005$ \\
\hline \multicolumn{4}{|c|}{ Rhyzopertha dominica } \\
\hline \multirow{4}{*}{ N Form } & 300 & $56.6 \pm 27.33 \mathrm{abcd}$ & $86.6 \pm 7.63 \mathrm{bc}$ \\
\hline & 400 & $78.3 \pm 7.63 \mathrm{abc}$ & $98.3 \pm 2.88 \mathrm{ab}$ \\
\hline & 500 & $91.6 \pm 7.63 \mathrm{ab}$ & $100.0 \pm 0.00 \mathrm{a}$ \\
\hline & 600 & $100.0 \pm 0.00 \mathrm{a}$ & $100.0 \pm 0.00 \mathrm{a}$ \\
\hline \multirow{5}{*}{ SilicoSec ${ }^{\circledR}$} & 300 & $36.6 \pm 5.77 \mathrm{~d}$ & $68.3 \pm 2.88 \mathrm{~d}$ \\
\hline & 400 & $40.0 \pm 8.66 \mathrm{~cd}$ & $71.6 \pm 2.88 \mathrm{~d}$ \\
\hline & 500 & $63.3 \pm 20.81 \mathrm{abcd}$ & $85.0 \pm 8.66 c$ \\
\hline & 600 & $90.0 \pm 10.00 \mathrm{ab}$ & $98.3 \pm 2.89 \mathrm{ab}$ \\
\hline & $\mathrm{F} / \mathrm{P}$ & $9.20 / 0.0001$ & $23.94 /<0.0001$ \\
\hline
\end{tabular}

${ }^{a}$ Means in the same column within each insect species followed by the same letters are not significantly different (for all treatments $d f=7,23$; Tukey's HSD, $p=0.05$ ). 
Table 3. Progeny (F1) population of three tested insect species after parent exposure to wheat and barley seeds treated with formulation $\mathrm{N}$ Form and DE SilicoSec ${ }^{\circledR}$.

\begin{tabular}{|c|c|c|c|c|c|c|c|}
\hline \multirow{2}{*}{ Treatment } & \multirow{2}{*}{ Concentration (ppm) } & \multicolumn{2}{|l|}{ S. Oryzae } & \multicolumn{2}{|l|}{ R. Dominica } & \multicolumn{2}{|l|}{ T. Castaneum } \\
\hline & & Number of Adults Mean $\pm \mathrm{SD}^{\mathrm{a}}$ & Inhibition (\%) & Number of Adults Mean $\pm \mathrm{SD}^{\mathrm{a}}$ & Inhibition (\%) & Number of Adults Mean $\pm S^{a}{ }^{a}$ & Inhibition (\%) \\
\hline \multicolumn{8}{|c|}{ Wheat } \\
\hline \multirow{6}{*}{ N Form } & 0 & $372.6 \pm 155.93 \mathrm{a}$ & - & $73.3 \pm 31.56 \mathrm{a}$ & - & $11.33 \pm 5.03 \mathrm{a}$ & - \\
\hline & 300 & $103.0 \pm 65.50 \mathrm{~b}$ & 72.4 & $4.6 \pm 0.57 \mathrm{~b}$ & 93.7 & $3.3 \pm 1.15 \mathrm{~b}$ & 70.8 \\
\hline & 400 & $19.6 \pm 13.01 \mathrm{~b}$ & 94.7 & $4.0 \pm 1.73 \mathrm{~b}$ & 94.5 & $2.0 \pm 1.73 \mathrm{~b}$ & 82.3 \\
\hline & 500 & $10.3 \pm 4.93 \mathrm{~b}$ & 97.2 & $4.3 \pm 3.05 \mathrm{~b}$ & 94.1 & $1.0 \pm 1.00 \mathrm{~b}$ & 91.2 \\
\hline & 600 & $7.3 \pm 3.78 \mathrm{~b}$ & 98.0 & $2.0 \pm 1.00 \mathrm{~b}$ & 97.3 & $0.0 \pm 0.00 \mathrm{~b}$ & 100.0 \\
\hline & $\mathrm{F} / \mathrm{P}$ & $12.68 / 0.0006$ & & $14.40 / 0.0004$ & & $10.04 / 0.0016$ & \\
\hline \multirow{6}{*}{ SilicoSec ${ }^{\circledR}$} & 0 & $372.6 \pm 155.93 a$ & - & $73.3 \pm 31.56 \mathrm{a}$ & - & $11.33 \pm 5.03 \mathrm{a}$ & - \\
\hline & 300 & $40.3 \pm 15.69 \mathrm{~b}$ & 89.2 & $14.6 \pm 3.51 \mathrm{~b}$ & 80.1 & $1.0 \pm 0.00 \mathrm{~b}$ & 91.2 \\
\hline & 400 & $32.6 \pm 25.71 \mathrm{~b}$ & 91.3 & $8.3 \pm 8.50 \mathrm{~b}$ & 88.7 & $1.3 \pm 0.57 \mathrm{~b}$ & 88.5 \\
\hline & 500 & $33.6 \pm 10.40 \mathrm{~b}$ & 91.0 & $3.3 \pm 0.57 b$ & 95.5 & $0.0 \pm 0.00 \mathrm{~b}$ & 100.0 \\
\hline & 600 & $20.3 \pm 3.51 \mathrm{~b}$ & 94.6 & $4.0 \pm 4.35 \mathrm{~b}$ & 94.5 & $0.6 \pm 1.15 b$ & 94.7 \\
\hline & $\mathrm{F} / \mathrm{P}$ & $13.79 / 0.0004$ & & $12.06 / 0.0008$ & & $12.58 / 0.0006$ & \\
\hline \multicolumn{8}{|c|}{ Barley } \\
\hline \multirow{6}{*}{ N Form } & 0 & $265.6 \pm 60.18 \mathrm{a}$ & - & $355.3 \pm 103.01 \mathrm{a}$ & - & $20.6 \pm 5.5 \mathrm{a}$ & - \\
\hline & 300 & $19.6 \pm 11.93 \mathrm{~b}$ & 92.6 & $31.3 \pm 12.58 \mathrm{~b}$ & 91.2 & $6.6 \pm 1.52 \mathrm{~b}$ & 68.0 \\
\hline & 400 & $10.3 \pm 12.09 \mathrm{~b}$ & 96.1 & $8.3 \pm 5.85 b$ & 96.7 & $1.3 \pm 1.15 \mathrm{~b}$ & 93.7 \\
\hline & 500 & $13.6 \pm 7.63 \mathrm{~b}$ & 94.9 & $7.6 \pm 1.52 \mathrm{~b}$ & 97.9 & $0.3 \pm 0.57 \mathrm{~b}$ & 98.5 \\
\hline & 600 & $10.6 \pm 8.08 \mathrm{~b}$ & 96.0 & $1.3 \pm 1.52$ & 99.6 & $0.3 \pm 0.57 \mathrm{~b}$ & 98.5 \\
\hline & $\mathrm{F} / \mathrm{P}$ & $47.30 /<0.0001$ & & $32.86 /<0.0001$ & & $32.61 /<0.0001$ & \\
\hline \multirow{6}{*}{ SilicoSec ${ }^{\circledR}$} & 0 & $265.6 \pm 60.18 \mathrm{a}$ & - & $355.3 \pm 103.01 \mathrm{a}$ & - & $20.6 \pm 5.5 \mathrm{a}$ & - \\
\hline & 300 & $45.3 \pm 14.01 \mathrm{~b}$ & 82.9 & $51.3 \pm 16.07 \mathrm{~b}$ & 85.6 & $6.0 \pm 1.73 \mathrm{~b}$ & 70.9 \\
\hline & 400 & $32.3 \pm 13.20 \mathrm{~b}$ & 87.8 & $31.3 \pm 4.16 \mathrm{~b}$ & 91.2 & $3.0 \pm 2.64 \mathrm{~b}$ & 85.4 \\
\hline & 500 & $27.3 \pm 16.25 b$ & 89.7 & $31.6 \pm 4.50 \mathrm{~b}$ & 91.1 & $1.3 \pm 1.52 \mathrm{~b}$ & 93.7 \\
\hline & 600 & $19.6 \pm 6.65 \mathrm{~b}$ & 92.6 & $11.6 \pm 3.78 b$ & 96.7 & $1.6 \pm 1.52 \mathrm{~b}$ & 92.2 \\
\hline & $\mathrm{F} / \mathrm{P}$ & $38.65 /<0.0001$ & & $29.07 /<0.0001$ & & $21.94 /<0.0001$ & \\
\hline
\end{tabular}

${ }^{a}$ Means in the same column within each treatment followed by the same letters are not significantly different (in all cases $d f=4,14$; Tukey's HSD, $p=0.05$ ). 


\section{Discussion}

This study indicates that developed formulation N Form based on DE SilicoSec ${ }^{\circledR}$ enhanced with botanicals (essential oil lavender, corn oil, and bay leaves dust) and silica gel showed high levels of protection of wheat and barley against all three insect species. Among the tested species, the most sensitive in wheat and barley was $S$. oryzae, with the highest average mortality rate after 14 days postexposure (96.2\% and $100.0 \%$, respectively), followed with $R$. dominica (89.8\% and 96.2\%, respectively) and T. castaneum (84.5\% and $94.9 \%$, respectively). Generally, lower sensitivity of Tribolium spp. adults than $S$. oryzae and $R$. dominica to different DE formulations was proven earlier through other studies [17-20]. The basis probably lies between the combinations of physiology, morphology, genetics, and behavior response of T. castaneum, like differences in epicuticle, mobility through the grain mass or ability of water loss recovery [21-23]. Treated adults of the rusty grain beetle Cryptolestes ferrugineus (Stephens), $R$. dominica, and T. castaneum with DE (500 ppm) showed different adsorption of DE particles, which corresponds with differences in their mortality [23]. The previous author revealed that the highest number of hair-like structures, the highest density of DE particles on the body, and the highest mortality are shown by C. ferrugineus, compared T. castaneum, which has very smooth skin surface and a low level of mortality.

N Form provided complete control of S. oryzae, R. dominica, and T. castaneum in barley and of $S$. oryzae and $R$. dominica in wheat. In regard to DE SilicoSec ${ }^{\circledR}$, developed formulation N Form showed higher activity against all three insect species; higher mortality rate both in wheat and barley; and higher average progeny inhibition rate, namely, in barley. Apparently, additional ingredients of formulation N Form, botanicals and silica gel, contributed to the higher efficacy of DE SilicoSec ${ }^{\circledR}$, with only $48 \%$ of DE within its composition. The most important disadvantage of DE usage in stored cereals protection is the application of high concentration for successful pest control, which impairs the quality of cereals, such as physical and mechanical properties of the grain. Thus, reducing quantity of DE and at the same time, retaining and improving its efficacy can be considered as a key effect in value of the developed formulation. In a previous study [24], additive effect was also recorded, after combining inert dust originated from Croatia, botanicals, silica gel, and pyrethrin. After 6 months, formulations F1H and F2H showed higher insecticidal effect than DE Celatom ${ }^{\circledR}$ Mn 51 in corn and wheat against $R$. dominica. There are many studies where DEs have been mixed with other products with the aim of improving its efficacy and reducing the limitations. Korunic and Fields [20] found that three DE-based formulations (with combinations of DE, silica gel, pyrethrin, dill essential oil, and disodium octaborate tetrahydrate-DOT and yeast) were effective at controlling insects at lower concentrations than DE alone, and at the same time, lower concentrations affected reduction of bulk density much less than DE used alone. In many cases, the synergy between DE and added substances greatly enhanced the effectiveness of a mixture and therefore, the needed effective concentrations of DE had been greatly reduced by approximately 4 to 10 times in the comparison with concentrations of DE when used alone [25]. In this study, N Form achieved higher average progeny inhibition rate than DE SilicoSec ${ }^{\circledR}$, particularly expressed in barley for all three insect species. It could be explained with the faster activity of N Form than activity of DE SilicoSec ${ }^{\circledR}$. The mortality rate of treated parents was higher after 7 days postexposure, which was directly reflected in lower progeny production. Probably, faster activity is related to additional products within the formulation N Form. Namely, silica gel Sipernat ${ }^{\circledR} 50$ S could have contributed to the fast initial effectiveness [3] and EO of lavender possessing the multiple modes of action against insects [26]. Stronger and faster mortality induced by formulation N Form consequently led to higher inhibition of progeny population compared to DE SilicoSec ${ }^{\circledR}$ used alone.

Overall, formulation N Form showed higher efficacy against tested insect species in barley than in wheat. Unlike in wheat, $100 \%$ mortality of all three insect species was reached only after 7 days postexposure. Consequently, the progeny inhibition rate of all three insect species was higher in barley. The explanation for those differences can be seen through multiple perspectives. First of all, DEs and formulations based on DE are not equally effective on all grain types [27], which is related to different 
adherence of DE influenced by different kernel size and protein content [28] or oil content. The effect on different types of commodities like rice, sorghum, rye, corn, and wheat was investigated on the efficacy of $\mathrm{DE}[7,29]$, based on physiochemical characteristics of the grain as a relevant factor in treatment effectiveness. In addition, a significant difference in efficacy of DE was observed in different classes or varieties of grain [30]. Second, different physiology and morphology of kernels, such as kernel hardness and nutritional value, can attribute to development and reproduction rate of insect species [28,31]. Contrary to N Form, the activity of DE SilicoSec ${ }^{\circledR}$ was lower in barley than in wheat against $S$. oryzae and $R$. dominica, which is another proof of enhanced effectiveness of the developed formulation.

\section{Conclusions}

Overall, results of this study indicate that natural formulation N Form, based on botanicals, silica gel, and DE, was highly effective against three major stored product insect species S. oryzae, R. dominica, and T. castaneum in wheat and barley. Achieving stronger efficacy than DE SilicoSec ${ }^{\circledR}$ applied alone, this study provides new information about the improvement of DE effectiveness, thus representing a contribution to further development of natural insecticides as a part of integrated pest management program. Future trials will be designed to test the activity of $\mathrm{N}$ Form against other stored insect species, on different types of surfaces in order to examine the possibility of use as a surface treatment of empty storage facilities. Additionally, tests of influence of $\mathrm{N}$ Form parameters of grain quality are planned to be implemented.

Author Contributions: Conceptualization, A.L.; methodology, A.L.; formal analysis, A.L. and I.P.; investigation, I.P.; resources, A.L., I.P., and V.R.; writing — original draft preparation, A.L. and I.P.; writing-review and editing, A.L., I.P., and V.R.; funding acquisition, A.L. and V.R. All authors have read and agreed to the published version of the manuscript.

Funding: The study was carried out within the research team of Environmentally acceptable plant protection (No. 1133) at the Faculty of Agrobiotechnical Sciences Osijek.

Acknowledgments: The authors wish to thank Agricultural Institute Osijek, Croatia, for providing the wheat and barley seeds for testing.

Conflicts of Interest: The authors declare no conflict of interest. The funders had no role in the design of the study; in the collection, analyses, or interpretation of data; in the writing of the manuscript; or in the decision to publish the results.

\section{References}

1. Subramanyam, B.; Roesli, R. Inert Dusts. In Alternatives to Pesticides in Stored-Product IPM.; Subramanyam, B., Hagstrum, D.W., Eds.; Springer: Boston, MA, USA, 2000; pp. 321-380. [CrossRef]

2. Shah, M.A.; Khan, A.A. Use of diatomaceous earth for the management of stored-product pests. Int. J. Pest Manag. 2014, 60, 100-113. [CrossRef]

3. Korunić, Z.; Rozman, V.; Liška, A.; Lucić, P. Laboratory tests on insecticidal effectiveness of disodium octaborate tetrahydrate, diatomaceous earth and amorphous silica gel against Sitophilus oryzae (L.) and their effect on wheat bulk density. Poljopr. Agric. 2017, 23, 3-10. [CrossRef]

4. Korunic, Z.; Fields, P.G.; Kovacs, M.I.P.; Noll, J.S.M.; Lukow, O.M.; Demianyk, C.J.; Shibley, K.J. The effect of diatomaceous earth on grain quality. Postharvest Biol. Technol. 1996, 9, 373-387. [CrossRef]

5. Liška, A.; Korunić, Z.; Rozman, V.; Halamić, J.; Galović, I.; Lucić, P.; Baličević, R. Efficacy of nine Croatian inert dusts against rice weevil Sitophilus oryzae L. (Coleoptera: Curculionidae) on wheat. Emir. J. Food Agric. 2017, 29, 485-494. [CrossRef]

6. Korunić, Z; Fields, P. The effect of grain moisture content and temperature on the efficacy of six diatomaceous earths against three stored-products beetles. In Proceedings of the 7th International Working Conference on Stored-Product Protection, Beijing, China, 14-19 October 1998; Jin, Z., Liang, Q., Liang, Y., Tan, X., Guan, L., Eds.; Sichuan Publishing House of Science and Technology: Chengdu, China, 1998; pp. 790-795.

7. Korunic, Z. Overview of undesirable effects of using diatomaceous earths for direct mixing with grains. Pestic. Phytomed. (Belgrade) 2016, 31, 9-18. [CrossRef] 
8. Liška, A.; Rozman, V.; Korunić, Z.; Halamić, J.; Galović, I.; Lucić, P.; Baličević, R. The potential of Croatian diatomaceous earths as grain protectant against three stored-product insects. Integr. Prot. Stored Prod. IOBC-WPRS Bull. 2015, 111, 107-113.

9. Vayias, B.J.; Athanassiou, C.G. Factors affecting the insecticidal efficacy of the diatomaceous earth formulation SilicoSec against adults and larvae of the confused flour beetle, Tribolium confusum Du Val (Coleoptera: Tenebrionidae). Crop Prot. 2004, 23, 565-573. [CrossRef]

10. Ziaee, M.; Ebadillahi, A.; Wakil, W. Integrating inert dusts with other technologies in stored product protection. Toxin Rev. 2019. [CrossRef]

11. Athanassiou, C.G.; Korunić, Z. Evaluation of two new diatomaceous earth formulations enhanced with abamectin and bitterbarkomycin, against four stored-grain beetle species. J. Stored Prod. Res. 2007, 43, 468-473. [CrossRef]

12. Khorrami, F.; Valizadegan, O.; Forouzan, M.; Soleymanzade, A. The antagonistic/synergistic effects of some medicinal plant essential oils, extracts and powders combined with Diatomaceous earth on red flour beetle, Tribolium castaneum Herbst (Cloepotera: Tenebrionidae). Arch. Phytopathol. Plant Prot. 2018, 51, 685-695. [CrossRef]

13. Korunić, Z.; Rozman, V. A synergistic mixture of diatomaceous earth and deltamethrin to control stored grain insects. In Proceedings of the 10th International Working Conference on Stored Product Protection, Estoril, Portugal, 27 June-2 July 2010; Carvalho, M.O., Fields, P.G., Adler, C.S., Arthur, F.H., Athanassiou, C.G., Campbell, J.F., Fleurat-Lessard, F., Flinn, P.W., Hodges, R.J., Isikber, A.A., et al., Eds.; Julius Kühn-Institut: Berlin, Germany, 2010; pp. 894-898.

14. Pierattini, E.C.; Bedini, S.; Venturi, F.; Ascrizzi, R.; Flamini, G.; Bocchino, R.; Girardi, J.; Giannotti, P.; Ferroni, G.; Conti, B. Sensory quality of essential oils and their synergistic effect with diatomaceous earth, for the control of stored grain insects. Insects 2019, 10, 114. [CrossRef] [PubMed]

15. Quarles, W. Diatomaceous earth for pest control. IPM Pract. 1992, 14, 1-11.

16. Mewis, I.; Ulrichs, C. Action of amorphous diatomaceous earth against different stages of the stored product pests Tribolium confusum, Tenebrio molitor, Sitophilus granarius and Plodia interpunctella. J. Stored Prod. Res. 2001, 37, 153-164. [CrossRef]

17. Fields, P.; Korunic, Z. The effect of grain moisture content and temperature on the efficacy of diatomaceous earth from different geographical locations. J. Stored Prod. Res. 2000, 36, 1-13. [CrossRef]

18. Athanassiou, C.G.; Kavallieratos, N.G.; Andris, N.S. Insecticidal effect of three diatomaceous earth formulations against adults of Sitophilus oryzae (Coleoptera: Curculionidae) and Tribolium confusum (Coleoptera: Tenebrionidae) on oat, rye and triticale. J. Econ. Entomol. 2004, 97, 2160-2167. [CrossRef]

19. Korunić, Z.; Liška, A.; Lucić, P.; Hamel, D.; Rozman, V. Evaluation of diatomaceous earth formulations enhanced with natural products against stored product insects. J. Stored Prod. Res. 2020, 86, 101565. [CrossRef]

20. Korunic, Z.; Fields, P.G. Evaluation of three new insecticide formulations based on inert dusts and botanicals against four stored-grain beetles. J. Stored Prod. Res. 2020, 88, 101633. [CrossRef]

21. Ebeling, W. Sorptive dusts for pest control. Ann. Rev. Entomol. 1971, 16, 123-158. [CrossRef]

22. Rigaux, M.; Haubruge, E.; Fields, P.G. Mechanisms for tolerance to diatomaceous earth between strains of Tribolium castaneum (Coleoptera: Tenebrionidae). Entomol. Exp. Appl. 2001, 101, 33-39. [CrossRef]

23. Losic, D.; Korunic, Z. Diatomaceous earth, a natural insecticide for stored grain protection: Recent progress and perspectives. In Diatom Nanotechnology: Progress and Emerging Applications; Losic, D., Ed.; RSC Publishing: Cambridge, UK, 2018; pp. 219-247. [CrossRef]

24. Liska, A.; Korunic, Z.; Rozman, V.; Lucic, P.; Balicevic, R.; Halamic, J.; Galovic, I. Evaluation of the potential value of the $\mathrm{F} 1 \mathrm{H}$ and $\mathrm{F} 2 \mathrm{H}$ formulations as grain protectants against Rhyzopertha dominica (Fabricius) (Coleoptera: Bostrichidae). In Proceedings of the 12th International Working Conference on Stored-Product Protection (IWCSPP), Berlin, Germany, 7-11 October 2018; Adler, C.S., Opit, G., Fürstenau, B., Müller-Blenkle, C., Kern, P., Arthur, F.H., Athanassiou, C.G., Bartosik, R., Campbell, J., Carvalho, M.O., et al., Eds.; Julius-Kühn-Institut: Berlin, Germany, 2018; pp. 540-546.

25. Korunic, Z.; Liska, A.; Rozman, V.; Lucic, P. A review of natural insecticides based on diatomaceous earth. Poljopr. Agric. 2016, 22, 10-18. [CrossRef] 
26. Germinara, G.S.; Di Stefano, M.G.; De Acustis, L.; Pati, S.; Delfine, S.; De Cristofaro, A.; Rotundo, G. Bioactivities of Lavandula angustifolia essential oil against the stored grain pest Sitophilus Granarius. Bull. Insectol. 2017, 70, 129-138.

27. Kavallieratos, N.G.; Athanassiou, C.G.; Pashalidou, F.G.; Andris, N.S.; Tomanović, Ž. Influence on grain type on the insecticidal efficacy of two diatomaceous earth formulations against Rhyzopertha dominica (F) (Coleoptera: Bostrichidae). Pest Manag. Sci. 2005, 61, 660-666. [CrossRef] [PubMed]

28. Kavallieratos, N.G.; Athanassiou, C.G.; Vayias, B.J.; Kotzamanidis, S.; Synodis, S.D. Efficacy and adherence ratio of diatomaceous earth and spinosad in three wheat varieties against three stored-product insect pests. J. Stored Prod. Res. 2010, 46, 73-80. [CrossRef]

29. Saeed, N.; Farooq, M.; Shakeel, M.; Ashraf, M. Effectiveness of an improved form of insecticide-based diatomaceous earth against four stored grain pests on different grain commodities. Environ. Sci. Pollut. Res. 2018, 25, 17012-17024. [CrossRef] [PubMed]

30. Paponja, I.; Liška, A.; Rozman, V.; Lucić, P. Application of inert dust diatomaceous earth in control of lesser grain borer Rhyzopertha dominica Fab. (Coleoptera: Bostrichidae) on varieties of wheat, rye and oats. Agron. J. 2017, 3, 87-98.

31. Breese, M.H. Studies on the oviposition of Rhyzopertha dominica (F.) in rice and paddy. Bull. Entomol. Res. 1962, 53, 621-637. [CrossRef]

(C) 2020 by the authors. Licensee MDPI, Basel, Switzerland. This article is an open access article distributed under the terms and conditions of the Creative Commons Attribution (CC BY) license (http://creativecommons.org/licenses/by/4.0/). 